\title{
ANALISIS PREFERENSI CALON PENABUNG SIMPANAN PEMUDA (SIMUDA) DI LEMBAGA KEUANGAN PERBANKAN
}

\author{
Towaf Totok Irawan \\ Universitas Pakuan, Bogor, Indonesia \\ Email: towaf@unpak.ac.id
}

\begin{abstract}
The purpose of this study is to describe the preferences of potential Simuda savers for prizes given by banks. This research was conducted on 300 respondents consisting of 100 Student Savers (Simple), 100 students and 100 employees. The sampling technique in this study is nonprobability sampling with a sampling quota, with data analysis techniques using descriptive statistics. The results of this study showed 50\% of respondents expressed an interest in saving on Simuda products, with prizes in the form of vouchers, direct prizes, sweepstakes, and the benefits of Simuda cards.
\end{abstract}

Keywords: preferences, gifts, Simuda

\section{ABSTRAK}

Tujuan penelitian ini adalah untuk mendeskripsikan preferensi calon penabung Simuda terhadap hadiah atau hadiah yang diberikan oleh perbankan. Penelitian ini dilakukan kepada 300 responden yang terdiri dari 100 penabung Simpanan Pelajar (Simpel), 100 mahasiswa dan 100 karyawan. Teknik sampling dalam kajian ini adalah nonprobability sampling dengan sampling quota, dengan teknik analisis data menggunakan statistik deskriptif. Hasil kajian ini menunjukkan $50 \%$ responden menyatakan berminat menabung di produk Simuda, dengan hadiah berupa voucher, hadiah langsung, undian, dan manfaat kartu Simuda.

Kata kunci: preferensi, hadiah, Simuda

\section{KETERANGAN ARTIKEL}

Riwayat Artikel: diterima: 11 Mei 2020; direvisi: 20 Mei 2020; disetujui: 2 Juni 2020

Klasifikasi JEL: G21

Cara Mensitasi: Irawan, Towaf T. (2020). Analisis Preferensi Calon Penabung Simpanan Pemuda (Simuda) di Lembaga Keuangan Perbankan. JIMFE (Jurnal IImiah Manajemen Fakultas Ekonomi), 6(1), 59-68.

https://doi.org/10.34203/jimfe.v6i1.2022

Copyright@2020. JIMFE (Jurnal Ilmiah Manajemen Fakultas Ekonomi) Universitas Pakuan

\section{PENDAHULUAN}

Keberadaan Tapera merupakan amanat dari UU No. 4/2016 tentang Tabungan Perumahan Rakyat, yang ditetapkan pada tanggal 24 Maret 2016. Dalam UU ini yang dimaksud dengan Tapera adalah tabungan perumahan yang dilakukan oleh masyarakat secara periodik dalam jangka waktu tertentu yang penggunaannya hanya untuk pembiayaan perumahan. Tujuan Tapera adalah menghimpun dan menyediakan dana murah jangka panjang yang berkelanjutan untuk pembiayaan perumahan dalam rangka memenuhi kebutuhan rumah yang layak dan terjangkau bagi peserta.

Menanggapi hal tersebut, kalangan perbankan perlu menciptakan strategi untuk menarik penabung dan calon penabung agar 
tertarik menabung di produk tabungan perbankan yang diberi nama Simpanan Pemuda (Simuda). Produk Simuda ini ditetapkan oleh perbankan sebagai produk tabungan yang nantinya akan diarahkan sebagai dana awal kepesertaan Tapera ketika kepesertaannya di Simuda berakhir.

Salah satu sasaran peserta Simuda adalah para penabung di Simpel (Simpanan Pelajar), yaitu siswa SMA/sederajat yang telah lulus sekolah. Umumnya para siswa ini lulus sekolah pada usia tujuh belas tahun. Berdasarkan UU No. 4/2016, peserta adalah setiap pekerja dan pekerja mandiri yang berpenghasilan paling sedikit sebesar upah minimum dan telah berusia paling rendah dua puluh tahun atau sudah kawin pada saat mendaftar. Apabila rata-rata usia peserta Simpel lulus sekolah pada usia tujuh belas tahun, tersedia waktu kurang lebih tiga tahun bagi peserta Simpel untuk beralih ke produk tabungan Simuda. Dalam hal ini, pada saat masa kepesertaan di Simpel berakhir, maka perbankan dapat mengalihkan kepesertaannya ke produk Simuda.

Potensi penabung Simuda tidak saja dapat dimobilisasi dari peserta Simpel, tetap juga dapat diarahkan kepada para pekerjaan dan mahasiswa yang usianya masih tergolong pemuda. Berdasarkan UU No. 40/2009, yang dimaksud pemuda adalah golongan penduduk yang berusia 16-30 tahun.

Menurut data BPS (2016), jumlah penduduk yang berusia 16-30 tahun sebanyak 64.308 .600 orang. Golongan pemuda ini masih dapat dipecah lagi menjadi beberapa kelompok usia, yaitu 16-17 tahun (3\%); 18-22 tahun (8\%); usia 23-26 tahun (7\%); dan 27-30 tahun (7\%). Dari komposisi golongan pemuda ini, jumlah pelajar aktif sebanyak 8.451.077 anak dan jumlah mahasiswa aktif adalah 8.585.800 orang. Dengan melihat komposisi jumlah pemuda ini, maka potensi mereka untuk dijadikan nasabah produk Simuda sangat besar. Jika kedua golongan pemuda itu dijumlahkan, angkanya akan mencapai 15.036.677 orang.
Menjadikan kalangan pemuda, baik itu peserta Simpel, mahasiswa, maupun pekerja, untuk menjadi penabung Simuda dapat dikatakan tidak mudah. Hal ini diperlukan hadiah tertentu yang diberikan oleh perbankan kepada calon penabung agar mereka tertarik menabung di Simuda. Berdasarkan pertimbangan ini, perlu dilakukan kajian terhadap kalangan pemuda tersebut untuk melihat preferensi mereka terhadap hadiah yang diinginkan. Hasil penelitian ini dapat digunakan oleh kalangan perbankan sebagai pertimbangan dalam memberikan hadiah kepada kalangan pemuda tersebut agar berminat menabung di Simuda.

\section{KAJIAN LITERATUR}

Schiffman dan Kanuk (2010) mendefinsikan perilaku konsumen sebagai perilaku yang ditunjukkan oleh konsumen. Sementara Engel et. al (1995) menekankan adanya tindakan langsung dan Swastha \& Handoko (1987) lebih memfokuskan pada tindakan pengambilan keputusan oleh individu. Kamus Besar Bahasa Indonesia mengartikan preferensi sebagai pilihan atau kesukaan (Balai Pustaka, 2012). Pakar lainnya mengartikan sebagai pilihan berdasarkan rangking atribut (Koo dkk.,1999; Munandar dkk., 2012). Pauli (1990) mengartikan sebagai sikap pelanggan atau konsumen.

Sukti dkk. (2017) menegaskan bahwa ada dua faktor internal dan eksternal yang mempengaruhi konsumen, khususnya nasabah bank. Faktor internal, meliputi pertama, faktor pribadi (usia, pekerjaan, pendapatan, dan jenis kelamin); kedua, psikologis (motivasi, persepsi dan pembelajaran); dan ketiga, faktor konsumen atau nasabah (kenyamanan, kesenangan, keamanan ketentraman, keuntungan, dan kebutuhan). Faktor eksternal, pertama, faktor budaya (agama, kelompok suku dan bahasa); kedua, faktor sosial (keluarga, teman, tetangga, peran dan status sosial); dan ketiga, faktor lembaga (bukti fisik, informasi, promosi, iklan, spanduk, lokasi, pelayanan, fasilitas, 
produk, dan kenyamanan nasabah). Kajian Safi'i (2016) menujukkan bahwa faktor-faktor yang mempengaruhi preferensi nasabah adalah trust, profit, service, religious, termasuk promosi (Pebriani dkk., 2018). Fadilah dkk. (2017) berpendapat bahwa pilihan konsumen didasarkan pada faktor-faktor preferensi yang berbeda-beda.

Kajian Andespa (2017) \& Alfiah (2019) menunjukan bahwa faktor pribadi berpengaruh terhadap minat menabung nasabah. Hasil ini berbeda dengan temuan Hartatie dkk. (2016). Kajian lainnya menunjukkan bahwa pendapatan tidak berpengaruh terhadap keputusan menjadi nasabah bank (Khasanah, 2016; Dewi, 2019; dan Sobria, 2016). Faktor pribadi seperti jenis kelamin berpengaruh terhadap produk perbankan (Arjunanta, 2011).

Beberapa peneltian lainnya menunjukkan bahwa hadiah memberikan pengaruh terhadap keputusan penggunaan kartu kredit oleh seseorang (Dewi, 2019). Jauh sebelumnya Reksoprayitno (1997) sudah membuktikan hasil penelitiannya bahwa ada hubungan signifikan antara hadiah dan keputusan menabung nasabah.

Berdasarkan tinjauan pustaka di atas, maka kerangka kerja penelitian ini adalah sebagai berikut:

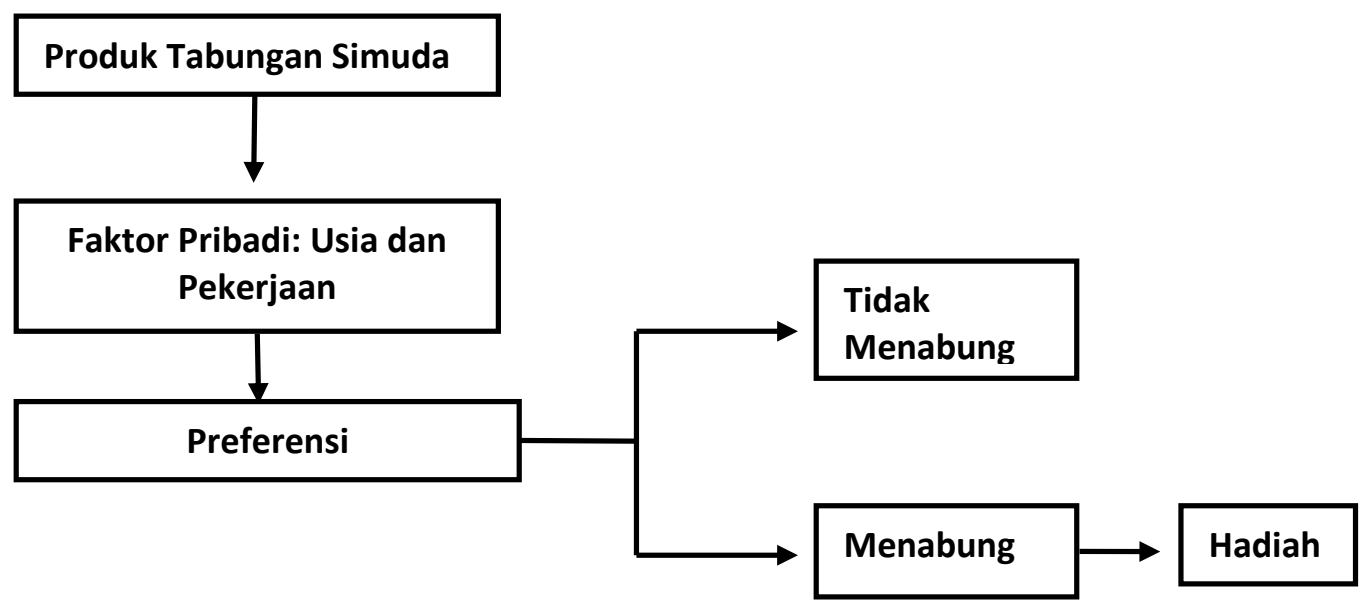

Gambar 1. Kerangka Kerja Kajian

\section{METODE PENELITIAN}

Desain penelitian ini adalah deskriptif. Menurut Sekaran \& Bougie (2009), penelitian deskriptif dilakukan untuk memverifikasi dan menggambarkan karakteristik spesifik dari variabel yang diteliti. Tujuan dari studi deskriptif adalah untuk menggambarkan profil yang tepat dari individu, insiden, fenomena atau situasi (Zukmund dkk., 2010).

Teknik sampling dalam penelitian ini menggunakan nonprobability sampling dengan teknik penarikan sampelnya adalah sampling kuota. Sampling kuota adalah teknik penentuan kuota dari populasi yang mempunyai ciri-ciri tertentu sampai jumlah yang diingin (Sugiono, 2009). Jumlah keluruhan sampel yang ditetapkan adalah 300 orang terdiri 100 orang penambung Simpel, 100 orang mahasiswa dan 100 pekerja. Teknik analisis data yang digunakan adalah statistik deskriptif. 


\section{HASIL PENELITIAN DAN PEMBAHASAN}

Untuk memancing tingkat kognitif responden tentang perumahan, responden diberikan pertanyaan tentang kepemilikan rumah. Hal ini penting ditanyakan kepada responden untuk melihat tingkat urgensi dari kepemilikan rumah menurut pendapat mereka.

Responden juga ditanyakan tentang produk tabungan Simuda. Pertanyaan ini diajukan untuk melihat preferensi calon nasabah terhadap produk Simuda dan alasannya berminat untuk menabung. Responden juga diberikan pertanyaan agar memberikan preferensinya atas benefit yang diharapkan dari produk Simuda. Lebih lanjut hasil penelitian dan pembahasan disampaikan di bawah ini.

\section{Terpikir memiliki rumah}

Secara umum responden pelajar, mahasiswa dan pekerja yang berusia antara $17 \mathrm{~s} / \mathrm{d}$ di bawah 30 tahun yang berhasil dihimpun pendapatnya, menyatakan bahwa saat ini mereka sudah terpikirkan untuk memiliki rumah. Sebesar $89 \%$ responden menyatakan sudah terpikirkan untuk memilki rumah. Hanya sekitar $11 \%$ reponden yang menyatakan saat ini belum terpikirkan untuk memiliki rumah. Dari $11 \%$ responden ini memberikan alasan rumah bukan urusannya sebanyak $20 \%$, dan karena alasan lain-lain $80 \%$.

Terkait dengan hal ini, menarik untuk mencermati data responden pelajar. Respendon pelajar SMA/SMK sebesar $89 \%$ saat ini sudah terpikirkan untuk memiliki rumah dan hanya $11 \%$ responden yang menyatakan belum terpikirkan untuk memiliki rumah. Dari $11 \%$ responden ini selanjutnya dilakukan pendalaman terkait alasan belum terpikirkan untuk memiliki rumah. Mereka memberikan alasan bukan urusannya sebanyak $100 \%$ (untuk pelajar SMA) dan alasan lainnya sebesar 100\% (untuk pelajar SMK).

Meskipun persentasenya menurun sedikit, kalangan responden mahasiswa paling banyak tetap menyatakan bahwa saat ini sudah terpikirkan untuk memiliki rumah dengan jumlah sebesar $76 \%$ dan sisanya belum terpikirkan memiliki rumah sebesar $24 \%$. Kelompok responden yang terakhir ini semua memberikan alasan lain-lain. Berbeda dengan responden pelajar dan mahasiswa, untuk responden pekerja sebesar $100 \%$ mereka saat ini sudah memikirkan untuk memiliki rumah.

\section{Berminat ikut program kepemilikan rumah}

Survei ini juga ingin mendapatkan informasi dari responden terkait keminatan responden terhadap program-program kepemilikan perumahan yang diselenggarakan oleh Pemerintah. Secara akumulatif responden yang menyatakan berminat sebesar $81 \%$ dan responden yang menyatakan tidak berminat sebanyak $19 \%$.

Setelah dilakukan pemetaan secara parsial, khusus responden pelajar yang menyatakan berminat mengikuti program kepemilikan rumah yang diselenggarakan oleh Pemerintah jumlahnya menurun yaitu sebesar 61\% (SMA) dan 85\% (SMK), dan responden menyatakan tidak berminat jumlahnya sebesar 39\% (SMA) dan 15\% (SMK).

Ketika pertanyaan yang sama dikonfirmasikan kepada kalangan responden mahasiswa, mereka yang menyatakan berminat untuk ikut program kepemilikan rumah yang diadakan oleh Pemerintah sebanyak $77 \%$, dan hanya $23 \%$ responden yang menyatakan tidak berminat. Pertanyaan yang sama ini kembali dikonfirmasi kepada responden pekerja, dan hasilmya 100\% responden pekerja menyatakan berminat untuk ikut program kepemilikan rumah yang diadakan oleh Pemerintah.

Jawaban dari pertanyaan ini dapat dipahami bahwa responden semakin bertambah usia, ditambah latar belakang status responden memberikan pengaruh atas keputusannya untuk mengikuti program kepemilikan rumah yang diselenggarakan oleh Pemerintah. 


\section{Berminat menabung di Simuda}

Terkait keinginan menabung di Simuda sebanyak $68 \%$ responden menyatakan berminat untuk menabung di Simuda. Sementara sebanyak $17 \%$ menyatakan tidak berminat menabung di Simuda, dan 15\% responden lainnya menyatakan lain-lain. Responden yang menyatakan tidak berminat menabung di Simuda karena alasan belum ingin punya rumah sebanyak $50 \%$; belum ingin berinvestasi sebanyak 29\%; dan lain-lain sebanyak $21 \%$.

Jlka dikonfirmasikan kepada responden pelajar, sebanyak 39\% (SMA) dan 95\% (SMK) yang berminat menabung di Simuda. Sebanyak 33\% (SMA) dan 5\% (SMK) menyatakan tidak berminat menabung di Simuda dan sebanyak 28\% (SMA) dan 0\% (SMK) menyatakan lainnya. Beberapa alasan yang disampaikan oleh responden pelajar untuk sementara ini yang tidak beminat untuk menabung di Simuda di antaranya karena belum ingin punya rumah sebanyak $34 \%$ (SMA) dan $100 \%$ (SMK); belum ingin berinvestasi sebanyak 33\% (SMA); dan selebihnya sebanyak 33\% (SMA) memberikan alasan lain-lain.

Jlka dikonfirmasi kepada responden mahasiswa, sebanyak 59\% menyatakan berminat. Sebanyak 23\% menyatakan tidak berminat menabung di Simuda, dan sebanyak $18 \%$ responden lainnya memberikan alasan lain-lain. Beberapa alasan yang disampaikan oleh responden mahasiswa yang tidak beminat untuk menabung di Simuda di antaranya karena belum ingin punya rumah sebanyak $80 \%$; dan belum ingin berinvestasi sebanyak $20 \%$.

Jika dikonfirmasi kepada kalangan responden pekerja, sebanyak $76 \%$ responden menyatakan berminat. Sebanyak $10 \%$ menyatakan tidak berminat menabung di Simuda, dan sebanyak $14 \%$ responden lainnya memberikan alasan lain-lain. Beberapa alasan yang disampaikan oleh responden pekerja yang tidak beminat untuk menabung di
Simuda di antaranya karena belum ingin investasi $50 \%$ dan sebanyak $50 \%$ responden memberikan alasan karena sebab lain.

Penarikan uang tidak dapat diambil sewaktuwaktu

Sebagian besar responden menyatakan setuju penarikan uang tidak dapat dilakukan sewaktu-waktu, yaitu sebanyak $72 \%$, dan menyatakan tidak setuju sebanyak $28 \%$. Banyak alasan responden yang setuju uang tidak diperbolehkan diambil sewaktu-waktu seperti pada Tabel 1 di bawah ini.

Tabel 1. Alasan Responden Tidak Menarik Uang Sewaktu-waktu

\begin{tabular}{cl}
\hline No. & \multicolumn{1}{c}{ Alasan } \\
\hline 1. & Untuk tujuan investasi \\
\hline 2. & $\begin{array}{l}\text { Supaya penggunaan uang } \\
\text { lebih hemat }\end{array}$ \\
\hline 3. & $\begin{array}{l}\text { Tetap menjaga semangat } \\
\text { untuk menabung }\end{array}$ \\
\hline 4. & Supaya uang dapat dikembangki \\
\hline 6. & Pencapaian target lebih efektif \\
\hline 7. & Agar terkelola dengan baik \\
\hline 8. & Untuk menghindari \\
& $\begin{array}{l}\text { penggunaan uang yang tidak } \\
\text { bermanfaat }\end{array}$ \\
\hline 9. & Penggunaan menjadi lebih \\
& terencana \\
\hline 10. & Untuk tindakan berjaga-jaga \\
\hline 11. & Untuk persiapan DP Rumah \\
\hline 12. & Menyukai program Simuda \\
\hline Sumber Suvei, 2019
\end{tabular}

Sumber: Survei, 2019

Responden pelajar yang menyatakan setuju jika uang tabungan tidak dapat ditarik sewaktu-waktu adalah sebanyak 78\% (SMA) dan 45\% (SMK) dan menyatakan tidak setuju sebanyak 22\% (SMA) dan 55\% (SMK). Alasan responden pelajar setuju jika uang tidak diperbolehkan ditarik sewaktu-waktu seperti pada Tabel 2 di bawah ini. 
Tabel 2. Alasan Responden Pelajar Tidak Menarik Uang Sewaktu-waktu

\begin{tabular}{cl}
\hline No. & \multicolumn{1}{c}{ Alasan } \\
\hline 1. & Supaya uang dapat dikembangkan \\
\hline 2. & $\begin{array}{l}\text { Menjadi lebih teratur dan disiplin } \\
\text { dalam penggunaan uang }\end{array}$ \\
\hline 3. & $\begin{array}{l}\text { Lebih berhati-hati dalam } \\
\text { menggunakan uang }\end{array}$ \\
\hline 4. & $\begin{array}{l}\text { Karena bukan tabungan untuk } \\
\text { kepentingan sehari-hari }\end{array}$ \\
\hline 5. & Supaya memiliki dana cadangan \\
\hline 6. & Mencegah sikap boros \\
\hline 7. & Untuk kepentingan investasi \\
\hline 8. & Untuk dapat mencapai target \\
\hline 9. & tabungan lebih efektif \\
\hline 10. & baik \\
\hline 11. & Karena diberlakukan meperti deposito \\
\hline 12. & Berjaga-jaga untuk di masa depan \\
\hline 13. & Menyukai programnya \\
\hline 14. & Lebih melatih kesabaran \\
\hline
\end{tabular}

Sumber: Survei, 2019

Untuk responden mahasiswa yang menyatakan setuju jika uang tabungan tidak dapat ditarik sewaktu-waktu sebanyak $70 \%$ dan yang menyatakan tidak setuju sebanyak $30 \%$. Alasan responden mahasiswa setuju atas pertanyaan bahwa uang tidak dapat ditarik waktu-waktu seperti pada Tabel 3 di bawah ini.
Tabel 3. Alasan Responden Mahasiswa Tidak Menarik Uang Sewaktu-waktu

No. Alasan

1. Karena butuh komitmen yang tinggi untuk konsisten menabung, dan pengambilan dalam waktu tertentu sangat membantu untuk mencegah pengambilan untuk hal-hal yang kurang penting

2. Memberikan waktu untuk berpikir dalam pengambilan tabungan

3. Menjadi lebih efektif

4. Agar tabungan ini khusus untuk tabungan yang dapat digunakan dalam jangka panjang

5. Dianggap uang lupa saja, karena jumlah yang disetorkan tiap waktunya jumlahnya tidak banyak

6. Agar tabungan tidak mudah habis

7. Jika tidak diberlakukan seperti deposito akan lebih boros karena bisa diambil kapan saja

8. Agar tidak boros

9. Biar orang tidak mengambil uangnya dalam keadaan apapun sampai waktu yang disepakati. Jadi uangnya bakal terkumpul terus dan semakin semangat buat mencapai targetnya

10. Agar uang tersebut tidak mudah dipakai untuk keperluan lain dan terfokus untuk tabungan rumah

11. Karena motivasi Investasi

12. Dapat memudahkan untuk mengontrol penarikan uang

Sumber: Survei, 2019

Responden pekerja yang menyatakan setuju jika uang tabungan tidak dapat ditarik sewaktu-waktu adalah sebanyak $100 \%$. Mereka memberikan pernyatakan setuju karena alasan seperti pada Tabel 4 di bawah ini. 
Tabel 4. Alasan Responden Pekerja Tidak Menarik Uang Sewaktu-waktu

\begin{tabular}{cl}
\hline No. & \multicolumn{1}{c}{ Alasan } \\
\hline 1. & $\begin{array}{l}\text { Agar tidak terpakai untuk hal yang kurang } \\
\text { bermanfaat }\end{array}$ \\
\hline 2. & Untuk kepentingan investasi \\
\hline 3. & $\begin{array}{l}\text { Agar dapat digunakan untuk kebutuhan } \\
\text { yg tepat dan sudah direncanakan, } \\
\text { sehingga terpakai untuk kebutuhan yg } \\
\text { mendadak }\end{array}$ \\
\hline 4. & Karena berniat khusus untuk menabung \\
\hline 5. & $\begin{array}{l}\text { Membiasakan diri agar disiplin dalam } \\
\text { penggunaan uang }\end{array}$ \\
\hline 6. & $\begin{array}{l}\text { Agar penggunaan uang fokus untuk } \\
\text { tujuan yang diinginkan seperti untuk } \\
\text { memiliki rumah }\end{array}$ \\
\hline 7. & $\begin{array}{l}\text { Agar uang terkumpul dalam jumlah } \\
\text { banyak }\end{array}$ \\
\hline 8. & $\begin{array}{l}\text { Agar memudahkan untuk uang muka } \\
\text { rumah }\end{array}$ \\
\hline
\end{tabular}

Sumber: Survei, 2019

\section{Hadiah yang diinginkan dari Simuda}

Secara umum lembaga keuangan perbankan memberikan hadiah kepada penabung terbagi dalam empat bagian, yaitu berupa pemberian hadiah langsung, undian, penukaran poin dan fasilitas kartu multifungsi.

Berdasarkan hasil survei yang dilakukan kepada responden pelajar, mahasiswa dan pekerja, hadiah yang diinginkan oleh mereka agar berminat menjadi penabung Simuda adalah Pelajar (Tabel 5), mahasiswa (Tabel 6), dan pekerja (Tabel 7).
Tabel 5. Hadiah yang Diinginkan Pelajar

No. Hadiah

1. Mendapatkan voucher belanja, voucher wisata

2. Hadiah langsung seperti motor

3. Mendapatkan undian berhadiah mobil, emas dan rumah

4. Pemberian uang cash

5. Pemberian asuransi

Sumber: Survei, 2019

Tabel 6. Hadiah yang Diinginkan Mahasiwa

No Hadiah

1. Mendapatkan diskon-diskon pembelian buku

2. Mendapatkan voucher belanja, voucher wisata

3. Dapat manfaat kartu Simuda di banyak tempat

4. Kemudahan menabung

5. Hadiah langsung alat- alat rumah tangga (seperti kulkas, mesin cuci, tv, dsb.)

6. Dapat undian berupa umroh, travelling, rumah, mobil, motor

Sumber: Survei, 2019 
Tabel 7. Hadiah yang Diinginkan Pekerja

\begin{tabular}{cl}
\hline No & \multicolumn{1}{c}{ Hadiah } \\
\hline 1. & Mendapatkan harga rumah murah \\
\hline 2. & $\begin{array}{l}\text { Mendapatkan voucher belanja } \\
\text { (tiap bulan), voucher wisata }\end{array}$ \\
\hline 3. & $\begin{array}{l}\text { Dapat manfaat kartu Simuda di } \\
\text { banyak tempat }\end{array}$ \\
\hline 4. & Dapat diwariskan \\
\hline 5. & $\begin{array}{l}\text { Hadiah langsung alat- alat rumah } \\
\text { tangga (seperti kulkas, mesin cuci, } \\
\text { tv, dan sebagainya) }\end{array}$ \\
\hline 6. & $\begin{array}{l}\text { Dapat undian berupa umroh, } \\
\text { travelling, rumah, mobil, motor, } \\
\text { haji untuk orang tua }\end{array}$ \\
\hline 7. & Mendapatkan beasiswa \\
\hline
\end{tabular}

Sumber: Survei, 2019

Setelah dilakukan inventarisasi terkait dengan hadiah yang diinginkan oleh kalangan responden pelajar, mahasiswa, dan pekerja di atas, maka dapat diidentifikasi hadiah tersebut ke dalam beberapa kelompok pertama, yang menginginkan hadiah dari Simuda berupa voucher yaitu voucher belanja dan voucher wisata; kelompok kedua, yang menginginkan peralatan elektronik untuk kebutuhan rumah tangga; kelompok ketiga mereka yang menginginkan menginginkan berupa umroh, naik haji, emas, motor, mobil dan rumah.

\section{PENUTUP}

Potensi pelajar dan mahasiswa dapat dihimpun menjadi nasabah Simuda sebanyak 15.036.677. Jumlah tersebut akan lebih besar lagi jika ditambah dengan pekerja usia di bawah tiga puluh tahun. Secara umum baik pelajar, mahasiswa dan pekerja yang berminat menjadi nasabah Simuda sebanyak 50\% dan yang tidak berminat $25,80 \%$. Sisanya sebanyak $3 \%$ menyatakan mungkin dan $21,20 \%$ memberikan alasan lain-lain. Alasan responden yang tidak berminat menabung di Simuda $23,10 \%$ belum ingin memiliki rumah; $7,60 \%$ belum tahu TAPERA; sebanyak $23,10 \%$ belum ingin berinvestasi; $3,80 \%$ belum mengerti sebanyak; 3,80\% sudah menabung di tempat lain; dan lain-lain sebanyak $19 \%$.

Responden semakin bertambah usia dan ditambah latar belakang status responden memberikan pengaruh atas keputusannya untuk mengikuti program kepemilikan rumah yang diselenggarakan oleh Pemerintah.

Hadiah yang diinginkan oleh kalangan responden pelajar, mahasiswa dan pekerja dapat diidentifikasi kedalam beberapa kelompok yaitu voucher, hadiah langsung, undian, dan manfaat kartu Simuda. Pemberian hadiah kepada nasabah Simuda dapat dilakukan dengan pendekatan pemberian hadiah langsung dan undian berhadiah. Pemberian hadiah langsung diberikan kepada nasabah saat selesai mendaftarkan diri sebagai nasabah Simuda. Sementara undian langsung diberikan melalui skema yang sudah ditetapkan oleh lembaga keuangan.

Kalangan responden pelajar, mahasiswa dan pekerja terkait hadiah dapat diidentifikasi ke dalam beberapa kelompok, yaitu pertama, yang menginginkan hadiah dari Simuda berupa voucher yaitu voucher belanja dan voucher wisata; kelompok kedua, yang menginginkan peralatan elektronik untuk kebutuhan rumah tangga; kelompok ketiga mereka yang menginginkan menginginkan berupa umroh, naik haji, emas, motor, mobil dan rumah.

Penelitian ini masih pada tahap eksplanasi, sehingga perlu penelitian yang lebih mendalam baik eksplorasi ataupun hypothesis testing. Penelitian lebih lanjut sangat diperlukan untuk menjawab pengaruh hadiah terhadap preferensi penabung Simuda.

Penelitian ini menggunakan teknik samping nonprobability sampling dengan teknik sampel sampling quota, dehingga dengan jumlah penabung simpel, mahasiswa dan pekerja yang demikian besar, penggunaan teknik sampling tersebut menjadi kurang representatif dikarenakan kurang mewakili besaran jumlah responden. Oleh karena itu, untuk penetapan perlu menggunakan pendekatan probability sampling agar tingkat keterwakilan populasi dapat dipenuhi. 


\section{REFERENSI}

Alfiah, L. (2019). Pengaruh faktor pribadi dan faktor psikologis terhadap keputusan nasabah memilih bank syariah di Kecamatan Ngaliyan. Disertasi. UIN Walisongo.

Andespa, R. (2017). Pengaruh Faktor Pribadi Terhadap Minat Menabung Nasabah di Bank Syariah. Al-Masraf: Jurnal Lembaga Keuangan dan Perbankan, 2(2), 193-206.

Arjunanta, I. (2011). Pengaruh karakteristik konsumen terhadap produk tabungan Bank BNI cabang Syariah Bumi Serpong Damai. Skripsi. UIN Syarif Hidayatullah.

Dewi, F. P. (2019). Pengaruh Pengetahuan, Persepsi Produk Dan Pendapatan Terhadap Minat Masyarakat Menabung Di Bank Syariah Kota Salatiga Dengan Religiusitas Sebagai Variabel Moderating. Disertasi. IAIN Salatiga.

Engel, J. F., dkk. (1995). Consumer Behavior. Eight Edition. New York: Holt, Rinehart, and Winston.

Fadilah, S., dkk. (2017). Analisis Preferensi Masyarakat Akademis pada ProdukProduk Perbankan Syariah: Studi Pada Dosen Perguruan Tinggi Islam di Bandung Raya. Kajian Akuntasi, 18(2), 164-173.

Hartatie, L. M., dkk. (2016). Pengaruh Pendapatan, Usia, dan Jangka Waktu Kredit terhadap Jumlah Kredit Pensiun Pada Pt Bank Tabungan Pensiunan Negara Cabang Surakarta. Jurnal Akuntansi Dan Sistem Teknologi Informasi, 12(2), 238-248.

Khasanah, A. (2016). Pengaruh Tingkat Pendidikan, Pendapatan, Motivasi Dan Promosi Terhadap Keputusan Menjadi Nasabah Lembaga Keuangan Syariah. Disertasi. IAIN Salatiga.

Koo, L. C., dkk. (1999). Preferential segmentation of restaurant attributes through conjoint analysis. International
Journal of Contemporary Hospitality management, 11(5), 242-253.

Munandar, J. M., \& Udin, F. Amelia. (2012). Analisis Faktor yang Mempengaruhi Preferensi Konsumen Produk Air Minum dalam Kemasan di Bogor. Journal of Agroindustrial Technology, 13(3), 97107.

Pauli, B. U., dkk. (1990). Organ-preference of metastasis. Cancer and Metastasis Reviews, 9(3), 175-189.

Pebriani, Sari I., dkk. (2018). Analisis Preferensi Nasabah Terhadap Produk Mitra iB Maslahah Bank BJB Syariah KCP Rawamangun. Jurnal Akuntansi, Keuangan, dan Perbankan, 5(1), 790797.

Safi'i, Aris M. (2016). Preferensi Masyarakat Terhadap Gadai Syariah (Studi Kasus Gadai Emas BRI Syariah Yogyakarta). Jurnal Hukum Islam. Jurnal Hukum Islam, 14(2), 53-72.

Schiffman, L. G. dan Kanuk. (2010) Consumer Behavior.

Sekaran, U. (2009). Research Methods for Business: A Skill Building Approach. UK: John Wiley \& Sons.

Sobria, E. (2016). Pengaruh Pengamalan Islam, Pendapatan Dan Pengetahuan Menabung Dalam Islam Terhadap Minat Menabung Mahasiswa lain Salatiga. Disertasi. IAIN Salatiga.

Sugiono. (2008). Metodologi Penelitian Bisnis. Bandung: Pusat Bahasa Depdiknas.

Sukti, S. dan Aliansyah, M. (2017). Preferensi Nasabah Non-Muslim Terhadap Bank Syariah (Studi pada Bank Syariah Mandiri Cabang Palangkaraya. Jurnal eLMashlahah, 7(2). 13-26.

Swastha, B., \& Handoko, D. D. T. H. (1987). Manajemen Pemasaran: Analisa Perilaku Konsumen. Cetakan kedua. Yogyakarta: Penerbit BPFE.

Zikmund, W. G., dkk. (2010). Business Research Methods. Mason, $\mathrm{OH}$ : SouthWestern, Cengage Learning. 
